\title{
Stock Price Fluctuations and Corporate Forecasts Disclosure: Evidence from an Emerging Market
}

\author{
Abbas Bagherian Kasgari (MBA) ${ }^{1}$, Keyvan Sheykhi ${ }^{2}$ \\ ${ }^{1}$ Islamic Azad University, Babol Branch, Iran \\ AbbasBagherian@yahoo.com, Abbas.Bagherian@seo.ir \\ ${ }^{2}$ Master in Accounting, Shahid Beheshti University, Iran \\ K.Sheykhi@gmail.com
}

\begin{abstract}
This research investigates the relation between forecasting report disclosure and stock price fluctuations. The first hypothesize examine if there is a relation between two variables among companies which lead to fluctuation in the stock price and the second hypothesize examined these variables over research industries.

Capital market reacts to new information-in most cases- at least one month before the official date of the disclosure. We found evidence of fluctuation in stock prices before disclosure indicate that information was released to the market before official disclosure. In the other word, stock prices react to the unofficially released information and rumors to the market around the releasing new officially disclosure date. This fraudulent attempt was initiated by price manipulation in cases which we don't see significant price change during forecasted disclosure even if there are significant change in reported earning values.

This investigation indicates that there is a significant relationship between releasing forecasted information and stock price fluctuations in the selected listed companies in TSE.
\end{abstract}

KEYWORDS: Forecasted Disclosure, Tehran Stock Exchange, Stock Price Fluctuation.

\section{Council for Innovative Research}

Peer Review Research Publishing System

Journal: International Journal of Management \& Information Technology

Vol. 9, No. 1

editor@cirworld.com

www.cirworld.com, member.cirworld.com 


\section{INTRODUCTION}

The disclosure of corporate annual forecast is a main topic in capital markets during recent years. This paper with attention to many researchers (Adina et Al, 2008; Barako et al, 2006; Akhtarudin, 2005; Omar et al, 2011 and others) empirically investigated the relationship between level of mandatory disclosure and and stock price fluctuations. Most of these inquiries appear to assume that an investor's belief and/or actions may be affected by the disclosure of management forecast and variable that could make affected such forecast.

Moonitz, Maurice(1961), constructed disclosure as an imperative postulate. He described it in negative terms:"...that is necessary to make them (accounting reports and forecast operations for the forthcoming year) not misleading."

Harry I. Wolk et al (2000) defined disclosure as refers to relevant information both inside and outside the main body of the financial statements themselves, including methods employed in financial statements where more than one choice exists or unusual or innovative selection of method arises.

DR.S.N. Maheshwari and S.K. Maheshwari (2009) worked on attribute of full disclosure. According to their research, accounting report should disclose fully and fairly the information they purport to represent. They should be honestly prepared and sufficiently disclose the information which is material interest proprietors, present and potential creditors and investors.

Eldon S.Hendrikson and Michael F. Van Breda (1991), researched about disclosure in the broadest sense of the word. They stated that disclosure simply means the release of information. Accountants tend to use the word in a slightly more restrictive sense to mean the release of financial information about a company within a financial report, generally annual report.

Disclosure takes place in two species: "a) mandatory disclosure, when regulatory authorities impose on companies to disclose certain elements of information; and b) voluntary disclosure, when companies decide to disclose more information than required because they deem that this will benefit them. Managers should carefully plan their disclosure strategy as the benefits include improved reputation of the company in market, less political and regulation intervention and enhanced stock liquidity" (Entwistle, 1997).

Most of the research so far has focused on exploring the voluntary rather than the mandatory disclosure (Einhorn, 2005), despite the fact that both mandatory and voluntary disclosures are potentially important (Omar et al, 2011) Indeed, voluntary disclosure, among others, lowers the cost of capital, increases the company market value and reduces the asymmetry of information (Bruslerie et al., 2010). Several studied examined the relationship between share price anticipation of earnings and voluntary disclosure (Hussainey et al., 2003; 2009; Healy et al., 2001). These findings suggest that when companies voluntarily increase the

Extent of disclosure and the ability of stock market to predict the changes of future earnings is considerably improved given the significant interaction between mandatory and voluntary disclosure (Yu, 2011).

But Despite these evident benefits, there were still concerns about how proper the disclosure was, due to the reporting options available to managers, as they could follow either the local GAAP or the IFRSs proposed by IASB. The situation has changed since 2005, insofar as IFRSs enhance the transparency of accounting numbers and reduce the scope for judgment and earnings manipulation (latridis, 2008).

The purpose of this study is to investigate the effect of mandatory disclosure of corporate forecasts on stock price behavior. The sample is included a list of companies in Tehran stock exchange (TSE) as an emerging market for a period of three years, from 2010 to 2012. In this light, the next section presents the literature review regarding disclosure, motives for disclosure, measurement techniques, and salient factors of disclosure extent. Then we discuss an overview of TSE and its disclosure rules for registered companies in Securities and Exchange Organization (SEO) of Iran. Next, the hypotheses, the methodology and the sample of the study are reported. The research findings are presented afterwards, and the last section deals with conclusions, limitations and recommendations.

\section{LITERATURE REVIEW}

Many research in domain of financial reporting during recent years covered various aspects of disclosure such as attribute of forecasting firms (e.g., George latridis, 2005; Roger Debreceny \& Asheq Rahman, 2005 and Eugene C.M. Cheng a, Stephen M. Courtenay, 2006), regulation (Bikki Jaggi and his colleagues, 2006), earning management (Merle Erickson, Shiing-wu Wang, 1999) and manager behavior (Shuping Chen and colleagues, 2002) to economic consequences of financial reporting. Financial reporting and disclosure are potentially important means for management to communicate firm performance and governance to outside investors. Paul M. Healy ${ }^{*}$, Krishna G. Palepu (2001) provided a framework for analyzing managers' reporting and disclosure decisions in a capital markets setting. Several researchers studied about determinant of ownership of disclosing firms (Cox, C.,1985), Miles Gietzmann, (2006) analyzed disclosure of timely and forward-looking statements in relation with strategic management of major institutional ownership and found that increased corporate disclosure of industry-specific, nonfinancial and non-reutilized information does increase the stability of the holdings by major institutional investors. Gerald K. Chaua, Sidney J. Gray, (2002) examined the association of ownership structure with the voluntary disclosures and Shuqing Luoa and colleagues (2006) examined the effect of voluntary disclosure on the relationship between current annual return, contemporaneous annual earnings and future earnings, and the influence of both 
ownership structure and proprietary cost on this relationship. They found that existence of outside block ownership significantly decreases managers' ability to limit voluntary disclosure. Quarterly reporting in a voluntary disclosure environment was studied by Asheq Razaur Rahman and his colleagues, (2007), They found that a firm with high growth prospects, large size and a technology orientation is likely to disclose earnings on a quarterly basis.

Some research works on mandatory or voluntary disclosure. Mandatory disclosure is governed by regulatory agencies in all countries around the world (Healy et al., 2001; Akhtaruddin, 2005). Regulators force companies to disclose information that companies may wish to hide (Darrough, 1993). One of the explanations for disclosure regulation is the concern of the regulatory bodies to safeguard the welfare of ordinary investors (Watts \& Zimmerman, 1986; Taplin et al., 2002). Regulators aim to redistribute the wealth between informed and uniformed investors by requiring a minimum level of disclosure, as the information gap among them is expected to shorten (Healy et al., 1999). Furthermore, the credibility of the information in capital markets is positively influenced by the existence of disclosure regulation, which also ensures companies' compliance to the regulatory requirements (Al-Htaybat et al., 2006).

Shuping and colleagues, 2002 investigated a pervasive voluntary disclosure practice including financial statements with quarterly earnings announcements. They found that managers voluntarily disclose balance sheets when current earnings are relatively less informative, or when future earnings are relatively more uncertain. Another research (Jeroen Suijs, 2006 and Eti Einhorn, 2007) acknowledged these results.

Concerning about accuracy and precision forecasts and abilities of firm to provide reliable report was topics of some other researches (Bikki Jaggi and et al, 2006; Hoje Jo, Yongtae Kim, 2007)

Gregory Waymire,(1986), has examined the relative accuracy of analyst earnings forecasts prepared both before (prior forecasts) and after (posterior forecasts) voluntary management earnings forecasts. The results of his investigation about the accuracy of analyst earnings forecasts before and after voluntary management forecasts suggested that management forecasts are more accurate than prior analyst forecasts and posterior analyst forecasts are no more accurate than management forecasts. His concluded that accuracy differences were the likely artifact of inside information held by the manager at the time of forecast disclosure. (Hassell J., R. Jennings et al, 1988)

The relation between insider activities and forecast disclosure were analyzed by several researches. Christopher F. Noe (1999) investigated the association between voluntary disclosures and insider transactions (i.e., transactions by managers in their own firms' shares). His findings suggested that managers do not make insider transactions to profit from news about their own firms just before it becomes publicly available. However, managers appear to employ other strategies for exploiting private information when making insider transactions. Also, managers take advantage of knowledge about their own firms' long-term prospects while utilizing voluntary disclosures to shield themselves against profiteering allegations. Other researcher found stronger evidence about using forecast discourse by insider users (Eugene F. Fama, 1970). Chena and colleagues,( 2002) studied about relation between disclosure regulation and the profitability of insider trading in New Zealand market. The results showed that insiders earn significantly large abnormal returns on their transactions, with the gains coming largely from transactions involving delayed disclosure. In contrast, transactions involving immediate disclosure earn insignificant returns. These findings strongly support the amendments to securities laws that require continuous disclosure for all transactions.

David Aboody and Ron Kasznik",(2000), investigated whether CEOs manage the timing of their voluntary disclosures around stock option awards. They conjectured that CEOs manage investors' expectations around award dates by delaying good news and rushing forward bad news. They found that CEOs make opportunistic voluntary disclosure decisions that maximize their stock option compensation. Also, Ranga Narayanan (1999), found that managers have use a partial disclosure policy for good or bad news where they have private information and opportunities to trade on it as Insider.

Roger Debreceny a, Asheq Rahman,(2005), studied about firm-specific determinants of continuous corporate disclosures. They attempt to identify the firm-specific determinants of discretionary disclosures. They examined the frequency and regularity of online announcements on the stock exchange websites of companies included in the Morgan Stanley Capital Index for small-cap firms in eight developed markets in Asia and Europe. They found that firms with higher information asymmetry have a higher frequency and regularity of continuous online reporting.

Ahmadpour and colleagues (2009), in their research investigate XBRL (Extensible Business Reporting Language) and growing interest in modern financial reporting technologies and disclosure among developing countries, this study examined the potential for implementing online financial reporting using extensible Business Reporting Language (XBRL) in Tehran Stock Exchange. The results of this research illustrated that there is a high level of efficiency in disclosure in modern financial reporting technology.

The issue of timeliness of financial reporting as an important qualitative characteristic of accounting information, has received much attention from regulatory and professional bodies in many countries in recent years. 'Does timeliness of mandatory corporate forecasts disclosure systematically influence stock prices in stock markets?' This question has received a good deal of attention in the financial disclosure literature. In a research paper, Lang, M. and R. Lundholm, (2000) has examined corporate disclosure activity around seasoned equity offerings and its relation to stock prices. In their sample, beginning six months before the offering, issuing firms dramatically increase their disclosure activity, particularly for the categories of disclosure over which firms have the most discretion. They found that firms which maintain a consistent level of disclosure experience price increases prior to the offering and only minor price declines at the offering announcement relative to the control firms, suggesting that disclosure may have 
reduced the information asymmetry inherent in the offering. They showed firms that substantially increase their disclosure activity in the six months prior to the offering also experience price increases prior to the offering relative to the control firms, but suffer much larger price declines at the announcement of their intent to issue equity, suggesting that the disclosure increase may have been used to "hype the stock" and the market may have partially corrected for the earlier price increase (Healy, P. and K. Palepu, 2001).

James M. Patell,(1976) researched about relation between cooperate forecasts of earning per share and stock price behavior. He found that there was a statistically significant upward price change during the week of forecast disclosure, beyond that explained by movement of the market as a whole. When using a measurement technique which includes sign, the price adjustment was, on average, of the same sign and magnitude as that which accompanied the subsequent announcement of realized annual earnings. Also, he found that during the two months preceding the disclosure of the forecast, price adjustment was in the same direction as the change in "native" expectations embodied in the forecast. Forecast which exceeded estimates of market expectations were preceded by positive price adjustments and forecasts which fell short of market expectations were preceded by negative price adjustments. Regardless of the sign of the estimated change in the market expectations of future earnings, on average, the immediate forecast week was the occasion of upward price revision. Subsequent price behavior was relatively level of the positive forecast group and continued to decline for negative forecast group. (Erickson, M. and S. Wang, 1999)

\section{MANDATORY FORECAST DISCLOSURE IN TEHRAN STOCK EXCHANGE}

The data on stocks traded on the Tehran Stock Exchange (TSE) in Iran show a market that is still developing. Significant restrictions remain, most prominently the continued US restrictions on direct investment. Recent annual returns of over $40 \%$ have placed it in the forefront of exchanges in developing countries. (Kevin R. Foster, Ali Kharazi, 2008). A government privatization plan revived the moribund TSE in 1989, which by the end of 2008 listed over 430 companies.

In TSE all companies are listed on two boards. Companies listed on the "First Board" must have capital of at least 20 billion Rails and be held sufficiently widely (the government cannot own a majority stake). (Bagherian Kasgeri, A., 2007)

By ratifying new capital market law in 22 November, 2005, Securities and Exchanges Organization of Iran is responsible for regulation on issuer companies. In the execution of the capital market law, companies in TSE are obliged to adapt to the "Disclosure Rule of Registered Companies in Securities and Exchange Organization (hereafter SEO)".

By another section of this rule, companies must disclose management forecasted yearly financial and forecast reports for companies and their consolidated at least 30 days before starting new financial year and comment of the auditor report to the maximum 20 days after disclosing issuer report. Also they must restate their forecasted report regarding to quarterly actual report to maximum 30 days after of ending of first, second and third quarter and also it is required to comment of the auditor report on forecasted report regarding to first 6 month actual report be disclosed maximum 20 days after disclosing issuer report. Also auditors must declare their comment on forecasted report when it seems to be a significant change in latest forecasted report maximum 20 days after disclosure date. (Statement of financial accounting concept, 1978)

Although, this rules was mandated before ratifying new capital market law but after that new supervision team have move more authority to involve issuer companies. There are some means like quarterly disclosure rankings and tax discount permission which help regulators to enforce this rule (Sadr Ara \& et al, 2011). Companies which don't adapt to these rules would be suspended and even in serious cases would be delisted from TSE.

Article 45 of capital market law prohibited insiders from trade based on their private information. Also insiders including mangers of companies are obliged to report their trade to SEO. In TSE, market supervision would halt trading of issuer companies in suspected cases to private information trading.

By the new act, Securities and Exchanges Organization as a regulatory firm in Iranian capital market is responsible for performing surveillance duties over TSE (Bagherian Kasgeri, A., 2007).

So, this paper intends to analyze prior forecast report of issuer companies in TSE and analyzes their impaction stock price fluctuation.

\section{HYPOTHESES, METHOD AND DATA}

\subsection{Hypothesis development}

In the recent years listed companies in the Tehran Stock Exchange have disclosed their annual forecast report and these events mostly lead to fluctuation in the stock prices. Fluctuation in the stock prices after mandatory disclosing forecast report arise this question that dose mandatory disclose of companies forecast information caused to fluctuation in the stock price. In this research we are looking for an answer to this question. For this purpose and also evaluating the relationship between companies forecast mandatory disclosure and stock price fluctuation, the first research hypothesis is: 
H1. Mandatory disclosure forecast report of company lead to fluctuation in the stock price.

Also many investors and financial annalists are interested to know the relation between events inside the companies to the whole industry. To find answer this question we examine the second hypothesis.

H2. Mandatory disclosure forecast reports in the industry lead to fluctuation in the industry stock price.

\subsection{Methodology}

In this research we intend to examine the relation between pair variables explaining goal of research. (Auditing Standards, 2005)

This is performed through analyzing the relation between disclosure of the forecast report and fluctuations in the stock price. So we defined two major pair variables. Variable $X$ represent stock price of the listed companies in Tehran Stock Exchange before disclosing forecast report. According to the martingale condition of prices, (Lang, M. and R. Lundholm, 2000) 5 observations before date of forecast disclosure are used for variable $X$.

Also, variable $\mathrm{Y}$ represent stock price of the listed companies in Tehran Stock Exchange after disclosing forecast report. According to the martingale condition of prices, (Lang, M. and R. Lundholm, 2000) 5 observations after date of forecast disclosure are used for these variables. One of the main objectives of the statistical analysis is to determine the relation between two variables. This paper uses statistical method for testing research hypothesis 1 . In this section we want to describe statistical method that is applied in this research.

Let to assume a population with the same attribute, like stock price of listed companies in Tehran stock Exchange. We distributed this population to before and after disclosed companies.

Now we used two kind of test, 1) Bootstrap test method for analysis of relation between disclosure and stock price fluctuation in level of TSE as a whole and 2) Paired sample t- student test method for analysis of relationship between disclosure and stock price fluctuation in level of companies and industries. In this section we want to examine paper hypothesis claim that stock price of companies that disclosed forecast report had fluctuation in comparison to that companies not disclosed their forecast report.

Considering $\mathrm{N}$ observation of this population, null hypothesis is defined as below:

$H_{0}: \mu_{d}=\mu_{n}$

Where:

$\mu_{d}$ : Mean stock price of the companies after disclosed their forecast report.

$\mu_{n}$ : Mean stock price of the companies before disclosed their forecast report.

We calculate sample mean and variance for each population by 660 observations. In order to perform this test:

$\bar{x}=$ Stock price mean in a given period for companies after disclosed their forecast

$\bar{y}=$ Stock price mean in a given period for companies before disclosed their forecast.

$S_{1}^{2}$ : Stock price variance in a given period for companies after disclosed their forecast.

$S_{2}^{2}$ : Stock price variance in a given period for companies before disclosed their forecast

Now we calculate test parameter as below:

$t_{\mathrm{o}}=\frac{\bar{x}-\bar{y}}{\sqrt{S_{p}^{2}}}$

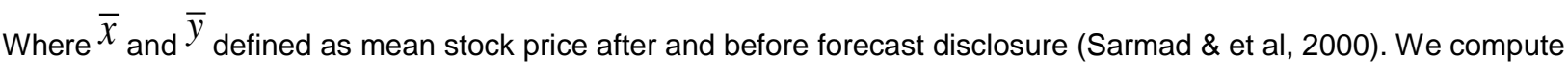

$$
S_{p}^{2}=\frac{\left(n_{1}-1\right) S_{1}^{2}+\left(n_{2}-1\right) S_{2}^{2}}{n_{1}+n_{2}-2}
$$

\footnotetext{
${ }^{1}$ examining hypothesis validity
} 
So using T-test table and regarding to statistical error $\alpha$ that commonly we get it 0.05 ( $\alpha=0.05$ ) to calculate $\boldsymbol{t}_{n_{1}+n_{2}-2, \alpha / 2}$ where $n_{1}+n_{2}-2$ is degree of freedom. With comparing $t_{0}$ and $\boldsymbol{t}_{n_{1}+n_{2}-2, \alpha / 2}$ conclude that:

We reject $\mathrm{HO}$ if $\left|t_{\mathrm{O}}\right|>t_{n_{1}+n_{2}-2, \alpha / 2}$ that means there is difference between two groups of after and before disclosed in companies. In the other hand if $\left|t_{0}\right|<t_{n_{1}+n_{2}-2, \alpha / 2}$ then we accept null hypothesis that means statistically there is no difference between two periods of time (Gourieroux \& Jasiak, 2001).

This method is used when two population are independent for each other. Whereas there are some dependencies in the populations we use Bootstrap-t test and paired sample t test for paired observation.

\subsection{Bootstrap-t Test Method}

We use Bootstrap-t test method for paired observation where we intend to analyze stock price before and after disclosure of forecast report in whole of market. The basic idea of bootstrapping is that inference about a population from sample data (sample -> population) can be modeled by resampling the sample data and performing inference on (resample -> sample). We define null hypothesis as below:

$H_{0}: \mu_{\text {before }}=\mu_{\text {after }}$

$H_{1}: \mu_{\text {before }} \neq \mu_{\text {after }}$

$\mu_{\text {before }}$ : Mean of stock price before disclosure of forecast report

$\mu_{\text {after }}$ : Mean of stock price after disclosure of forecast report

The bootstrap begins with an original sample taken from the population, then calculates sample statistics. Next, the bootstrap copies the original sample several times to create a pseudopopulation. The bootstrap uses the empirical density function (EDF) (Efron and Tibshirani, 1993). From the pseudopopulation, the bootstrap draws several samples with replacement (Efron and Tibshirani, 1993). The bootstrap's strength is its ability to develop a sample that is the same size of the original sample that may include an observation several times while omitting other observations. Random sampling with replacement provides different samples from the original sample. As the bootstrap draws the samples with replacement, it calculates statistics for each sample.

\subsection{Paired Sample t-test Method}

We use Paired sample-t test method for paired observation where we intend to analyze stock price before and after disclosure of forecast report. We define null hypothesis as below:

$H_{0}: \mu_{\text {befor }}=\mu_{\text {after }}$

$\mu_{b}$ : Mean of stock price before disclosure of forecast report

$\mu_{a}$ : Mean of stock price after disclosure of forecast report

In this method we assume $x_{i}$ for saving attribute values before test and $y_{i}$ for after test attribute values. We calculate $d_{i}=y_{i}-x_{i}$ for difference value and use $t_{0}$ as test parameter. Above null hypothesis is equivalent to $H_{0}: \mu_{d}=0$. So we define $t_{0}$ test parameter for performing $T^{2}$-test as below:

$t_{0}=\frac{\bar{d}}{\sqrt{S_{\bar{d}}^{2}}}$

Where:

$\bar{d}=\frac{1}{n} \sum_{i=1}^{n} d_{i} d_{i \text { mean and also }} S_{d}^{2}=\frac{1}{n-1} \sum_{i=1}^{n}\left(d_{i}-\bar{d}\right)^{2} d_{i \text { variance. }}$

Then we analyze the results using t-student table and comparing $\boldsymbol{t}_{n-1, \alpha / 2}$ to $t_{0}$ whereas: 
We reject $H_{0}$ if $\left|t_{0}\right|>t_{n-1, \alpha / 2}$. It mean there significant difference between stock fluctuation before and after disclosure. In the other word, there is a relationship between mandatory disclosure of forecast report and stock price fluctuation.

\subsection{Data and sample selection}

Method of this paper for data collection was statistical sampling. In this research stock price data for period from 2010 ending to 2012 was provided from Tehran Stock Exchange official website that is accessible with address http://www.irbourse.com. We get 5 day window for stock price around the forecast disclosure date. We explain more this approach in this section.

The martingale condition of prices implies that the best (nonlinear) prediction of the future price is the current price (Miraskari \& et al, 2011; Saeedi \& et al, 2012). The current price conveys all information that can help to predict next price that can be directly used as a predictor (Lang, M., 2000). Regarding to this theorem we collection our sample from 3 years period ending to 2012 that are accessible and updated.

We collected 5 observations for pre-disclosure period for monitoring treatment prior to disclosure and 5 observations for post-disclosure period as well. In the same vein, disclosure data of listed companies was provided by securities and exchange organization of Iran.

Statistical population of this research included 377 listed companies in the TSE that belong to 18 industry groups. We find disclosure date of companies from Surveillance on Issuer of Office in Securities and Exchange Organization of Iran. For running the research method we consider below limitations in selecting companies:

1. Companies that their financial year was ended to the March (In most of the Persian companies financial year is March because is matched to end of Persian year.)

2. Companies that have disclosed their forecast report during the period from 2010 ending to the 2012.

3. There was trade prior and after disclosing forecast report. or

4. Their forecast report was disclosed before due date of begin of May.(By TSE disclosure rule Persian company's due date for late issuing forecast report is end of April.)

Regarding to above limitation from 377 listed companies in TSE 44 companies was selected to be considered in this research.

\section{DATA ANALYSIS AND EMPIRICAL RESULTS}

\subsection{Findings}

In this section we discussed about our finding for accepting or rejecting research's hypothesizes. As mentioned in the previous section, we select 44 companies to be considered in research that their data are reported in the appendix 1. We have two hypothesizes. We used paired repeated observation and post and pre-Test values analysis for examining each hypothesizes.

Hypothesis 1: Disclosing forecasted company's reports lead to fluctuation in their stock prices.

Hypothesis 2: Disclosing forecasted industry's reports lead to fluctuation in their stock prices.

For examining above hypothesizes we applied paired repeated observation method for inferring using T2 parameter.

\subsubsection{Analyzing relation between forecasted financial report disclosure and stock price fluctuations}

At first, we examined the relationship between disclosure and stock price fluctuation in TSE as a whole. For that we used Bootstrap-t test. In this method, we have 660 observations, the bootstrap process is start by a random sampling with stable size and resampling again and again. For $95 \%$ confidence intervals we needed at least 39 observations $^{2}$ to processing. The result of Bootstrap-t test is show in table 1 and the output of software is showed in appendix 1 .

Table 1: The result of Bootstrap paired sample test in TSE as whole

\begin{tabular}{|l|l|l|l|}
\hline & Mean & Std. Error Mean & Sig. (2-tailed) \\
\hline Pair1 x-y & -169.215 & 101.74 & 0.475 \\
\hline
\end{tabular}

As can be seen, the significant of bootstrap test is 0.475 that is greater than 0.05 and in $95 \%$ confidence interval, $\mathrm{H}_{1}$ Hypothesis is rejected and the $\mathrm{H}_{0}$ hypothesis will be accepted. The result illustrated that in Tehran stock exchange,

\footnotetext{
${ }^{2}$ Based on SPSS software
} 
mandatory disclosure have not information content, in other words, the mandatory disclosure have not any relationship with stock price fluctuations. In the following, we evaluate two hypotheses of this research.

For analysis of 44 sample companies, both sectional and general analysis methods are used for finding relations between variables. In this section we report the findings for companies and industries in statistical tables.

To compare two types of period for hypothesizes 1 and 2, we measured paired variables in three years. For any company, we have 15 observations before disclosure and same amount after disclosure. To compare variables in two tables, we have

$t_{n-1,(\alpha / 2)}=t_{14,0.025}=2.145$

If $t$-statistics parameter for any paired was more than 2.145 then we would accept the hypothesis and if not we would reject it for that case. This variables use for testing hypothesis 1 and 2. This results prove that there is (not) a significant relationship between forecast report disclosure and stock price fluctuations in the yearly period from 2010 to 2012 for each company/industry.

\subsubsection{Findings for hypothesizes 1: Companies}

Table 1 reported the investigation results of 44 companies in the research sample. We will reject the null hypothesis if the test parameter value in the first column (table 2) be greater than 2.145. In the other word, in such cases there is significant relation between company price fluctuation and disclosure of forecasted report.

Table2: The results of test hypothesis 1 for 44 sample Companies during years 2010-12

\begin{tabular}{|c|c|c|}
\hline Company Name & Paired Sample-t Test coefficient & Sig \\
\hline Daroupakhsh Pharmaceutical Mfg. & 1.346 & 0.200 \\
\hline Daroupakhsh Pharmacy & -2.250 & 0.041 \\
\hline Daroupakhsh Pharmacy chemical & -0.840 & 0.415 \\
\hline Osvah Pharmacutical Co. & 2.167 & 0.048 \\
\hline Zahravi Pharmacutical Co. & -2.198 & 0.045 \\
\hline Razak Laboratories & -3.046 & 0.009 \\
\hline Abouraihan Pharmaceutical Co. & -2.466 & 0.027 \\
\hline Kowsar Pharmacutical Co. & 5.097 & 0.000 \\
\hline Rouz Darou Pharmacutical & -0.175 & 0.864 \\
\hline Iran Parenteral Products Co. & -0.595 & 0.561 \\
\hline Exir Pharmacutical Co. & -1.010 & 0.330 \\
\hline Damloran Pharmacutical Co. & -3.233 & 0.006 \\
\hline Loghman Pharmacutical Co. & -2.592 & 0.021 \\
\hline Iran Carbon Co. & -1.657 & 0.120 \\
\hline Khark Petrochemical Co. & 1.527 & 0.149 \\
\hline Nirocholor Co. & 3.810 & 0.002 \\
\hline Loabiran Co. & -1.991 & 0.066 \\
\hline Ardebil Cement Co. & 0.231 & 0.820 \\
\hline Shargh Cement Co. & 2.794 & 0.014 \\
\hline Sepahan Cement Co. & 2.990 & 0.010 \\
\hline Ardekan Ind.Ceramic Co. & -2.362 & 0.033 \\
\hline Glass And Gas Co & -2.623 & 0.020 \\
\hline Iran China Clay ind.Co. & 3.549 & 0.003 \\
\hline Iran Tractor Mfg.Co. & -0.101 & 0.921 \\
\hline Pars Khodro Co. & 0.436 & 0.670 \\
\hline Electric Khodro Shargh Co. & -6.458 & 0.000 \\
\hline
\end{tabular}




\begin{tabular}{|c|c|c|}
\hline Chadormalu Mineral Ind. & 1.146 & 0.271 \\
\hline Metals \& Min Co. & 3.042 & 0.009 \\
\hline Sepahan Industrial Group Co. & -0.889 & 0.389 \\
\hline Iran M. \& P. M & 0.927 & 0.418 \\
\hline Khoy Sugar Co.(Shahd) & -0.835 & 0.032 \\
\hline Noush Mazandaran Inc. & -2.376 & 0.029 \\
\hline Rayan Saipa & -2.428 & 0.000 \\
\hline Iran Leasing Co. & 5.579 & 0.949 \\
\hline Firoza Co. & 0.066 & 0.002 \\
\hline Iran Combin Mfg.Co. & -3.829 & 0.037 \\
\hline Pars Tile Co. & 2.307 & 0.491 \\
\hline Alvand Tile Ceramic Ind. & -0.707 & 0.006 \\
\hline Sand Foundry prepration Co. & -3.274 & 0.292 \\
\hline Iran Argham Co. & -1.096 & 0.571 \\
\hline Kaveh Paper Ind. & 0.581 & 0.162 \\
\hline Negin Tabas Lignite Co. & -1.476 & 0.015 \\
\hline Pars International Mfg.Co. & -2.778 & 0.163 \\
\hline Iran Transfo Co. & -1.473 & \\
\hline Fan & & \\
\hline
\end{tabular}

For eliminating the effect of external variables which would affected on company price fluctuation, the differences between industry indices' trend and stock price is analyzed to the resulted be confirmed. This way, for industries which had little number of companies (less that 15) the stock exchange index is used for comparison of trend.

\subsubsection{Findings for hypothesizes 2: Industries}

In this section the findings for 11 sample industries are reported in statistical table 3 . Same as the Table 2 , we will reject the null hypothesis if the test parameter value in the first column be greater than t-statistical. Because of different between the degree of freedom in any industry from another, we use significant value which in $95 \%$ confidence interval is 0.05 . In the other word, in such cases there is significant relation between industry price index fluctuation and disclosure events.

Table 3: The results of test hypothesis 2 for 11 sample industries during years 2010-12

\begin{tabular}{|c|c|c|}
\hline Name Industry & Paired Sample-T Test & Sig \\
\hline Pharmaceuticals & -1.750 & 0.082 \\
\hline Chemicals \& By-products & 0.360 & 0.720 \\
\hline Cement, Lime \& Gypsum & 1.690 & 0.098 \\
\hline Other Non-metallic Mineral Products & -0.746 & 0.459 \\
\hline Motor Vehicles And Auto Parts & -0.660 & 0.513 \\
\hline Metal Ores Mining & 2.817 & 0.009 \\
\hline Basic Metals & 0.271 & 0.788 \\
\hline Food and Non-sugar Products & -2.254 & 0.032 \\
\hline Other Financial Intermediaries & -2.019 & 0.053 \\
\hline
\end{tabular}




\begin{tabular}{|c|c|c|}
\hline Machinery \& Equipment & -2.333 & 0.027 \\
\hline Textiles & 1.928 & 0.064 \\
\hline
\end{tabular}

\subsection{Analysis of results}

Providing relevant, reliable and timely information is an important goal of financial reporting. Only in such situation, investors can make a rational decision. For this purpose, companies should disclose their forecast report to make it possible for investors to draw a prospective for the future. This can lead to a decrease in risk of investment in stock. Results of current research would help investor to have a better prospective in Tehran Stock Exchange. In this section we summarize the results.

\subsubsection{Analysis of the results for hypothesis 1}

The research results for $\mathrm{H}_{1}$ are divided in two groups. Table 4 demonstrated the list of companies that $\mathrm{H}_{1}$ is not rejected for them and table 5 included the list of companies that have not such situation. There are 8 companies which have no significant change in their forecasted reported value but their prices were affected during disclosure date. It seems this is because of affecting their market by rumors which were disclosed by speculators.

Based on information dissemination rules for registered issuer companies in TSE, in case of disseminating rumors, false or misleading information or reports among market participants, issuer companies must provide urgent disclosure to Securities and Exchange Organization of Iran to be disseminated among market participants.

As table 5 showed there were five companies with no significant change in reported forecast report. It seems that rumors were the motivation for price movement for these companies.

In such cases, surveillance on issuers department in Securities and Exchange Organization of Iran investigates need for further disclosure by issuer companies or halting trade for confirming about fair distribution information among all investors. Although, the supervision department in Tehran Stock Exchange is responsible for investigating probable market manipulation evidences.

Table 4: list of companies that $H_{1}$ is accepted for them

\begin{tabular}{|c|c|c|c|c|}
\hline & \multirow[b]{2}{*}{ Company Name } & \multicolumn{3}{|c|}{ Reasons for accepting Hypothesis 1} \\
\hline & & & Sianificant Change in & Rumors / \\
\hline 1 & Daroupakhsh Pharmacy chemical & $\checkmark$ & $\checkmark$ & - \\
\hline 2 & Osvah Pharmaceutical Co. & $\checkmark$ & - & $\checkmark$ \\
\hline 3 & Zahravi Pharmaceutical Co. & $\checkmark$ & $\checkmark$ & - \\
\hline 4 & Abouraihan Pharmaceutical Co. & & $\checkmark$ & - \\
\hline 5 & Rouz Darou Pharmaceutical & $\checkmark$ & - & $\checkmark$ \\
\hline 6 & Kowsar Pharmaceutical Co. & $\checkmark$ & $\checkmark$ & - \\
\hline 7 & Damloran Pharmacutical Co. & $\checkmark$ & $\checkmark$ & - \\
\hline 8 & Loghman Pharmacutical Co. & $\checkmark$ & - & $\checkmark$ \\
\hline 9 & Nirocholor Co. & $\checkmark$ & $\checkmark$ & - \\
\hline 10 & Loabiran Co. & $\checkmark$ & - & $\checkmark$ \\
\hline 11 & Shargh Cement Co. & $\checkmark$ & $\checkmark$ & - \\
\hline 12 & Sepahan Cement Co. & $\checkmark$ & $\checkmark$ & - \\
\hline 13 & Ardekan Ind.Ceramic Co. & $\checkmark$ & $\checkmark$ & - \\
\hline 14 & Glass And Gas Co & $\checkmark$ & $\checkmark$ & - \\
\hline
\end{tabular}




\begin{tabular}{|l|c|c|c|c|}
\hline 15 & Iran China Clay ind.Co. & $\checkmark$ & $\checkmark$ & - \\
\hline 16 & Electric Khodro Shargh Co. & $\checkmark$ & $\checkmark$ & - \\
\hline 17 & Metals \& Min Co. & $\checkmark$ & - & $\checkmark$ \\
\hline 18 & Noush Mazandaran Inc. & $\checkmark$ & $\checkmark$ & $\checkmark$ \\
\hline 19 & Rayan Saipa & $\checkmark$ & $\checkmark$ & - \\
\hline 20 & Iran Leasing Co. & $\checkmark$ & $\checkmark$ & $\checkmark$ \\
\hline 21 & Iran Combin Mfg.Co. & $\checkmark$ & - & $\checkmark$ \\
\hline 22 & Pars Tile Co. & $\checkmark$ & - & - \\
\hline 23 & Sand Foundry prepration Co. & $\checkmark$ & $\checkmark$ & \\
\hline 24 & Pars International Mfg.Co. & $\checkmark$ & $\checkmark$ & \\
\hline
\end{tabular}

Although there are companies (displayed in table 5) that had timely disclosure but $\mathrm{H}_{1}$ is rejected about these companies because of having no significant change in their reported value or affecting information on prices before disclosure date. Interestingly there were only three evidences of high changes in price before disclosure which was detected prior to disclosure window.

Prices change before disclosure date would be results of information asymmetry. So, we can investigate them for finding evidence for private information trading in these companies.

Table 5: List of companies that $H_{1}$ is rejected for them

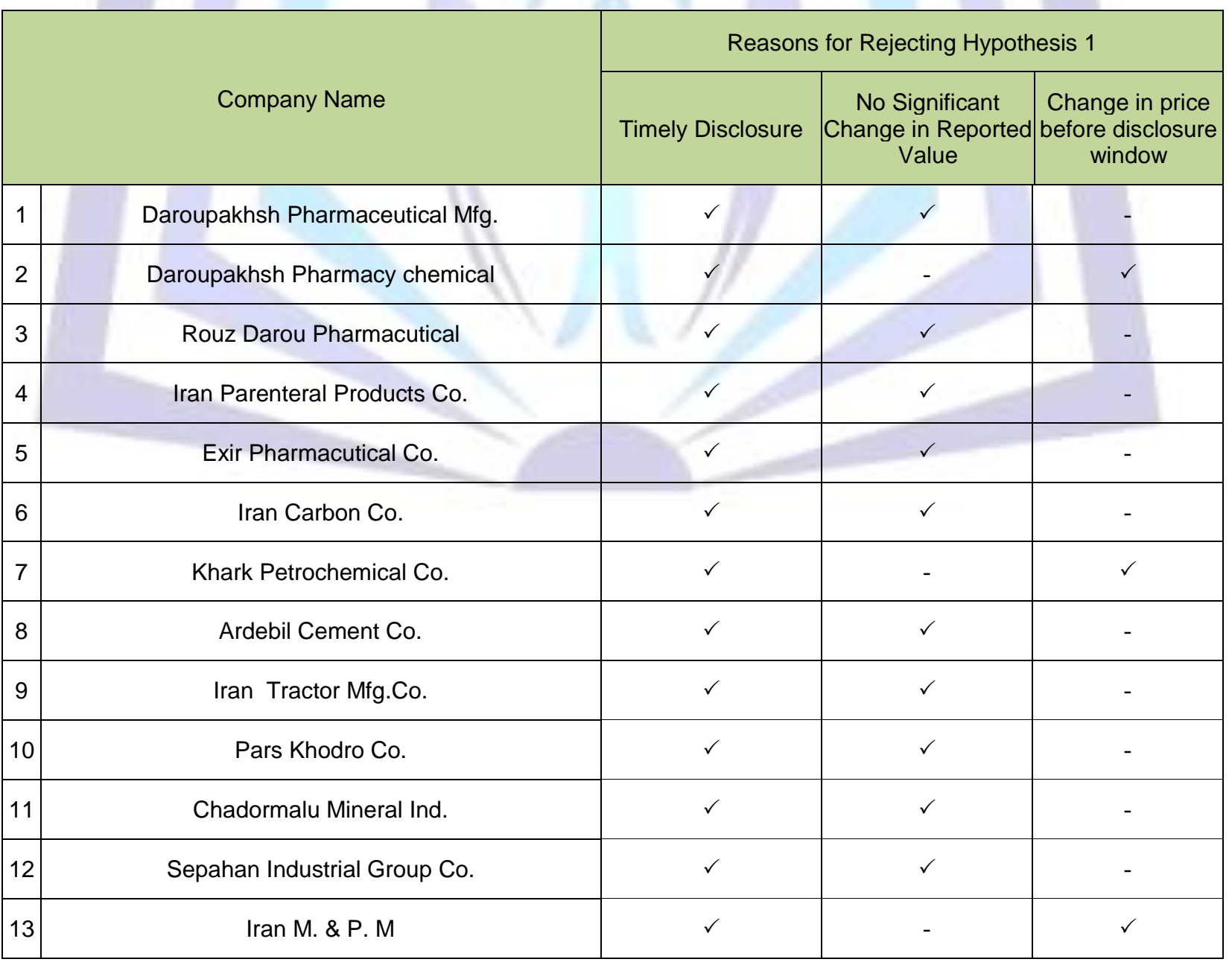




\begin{tabular}{|c|c|c|c|c|}
\hline 14 & Khoy Sugar Co.(Shahd) & $\checkmark$ & $\checkmark$ & - \\
\hline 15 & Firoza Co. & $\checkmark$ & $\checkmark$ & - \\
\hline 16 & Alvand Tile Ceramic Ind. & $\checkmark$ & $\checkmark$ & - \\
\hline 17 & Iran Argham Co. & $\checkmark$ & $\checkmark$ & - \\
\hline 18 & Kaveh Paper Ind. & $\checkmark$ & $\checkmark$ & - \\
\hline 19 & Negin Tabas Lignite Co. & & & \\
\hline 20 & Iran Transfo Co. & & & \\
\hline
\end{tabular}

\subsubsection{Analysis of the results for hypothesis 2}

The results of research for $\mathrm{H}_{2}$ are divided in two groups. Table 6 is demonstrated the list of industries that $\mathrm{H}_{2}$ is accepted for them and table 7 is demonstrated the list of industries that $\mathrm{H}_{2}$ is rejected for them. The first group Industries had considerable increase/decrease in their forecast but the second group hadn't significant changes in their reported value that are suspected to have some evidence about information asymmetric. By reviewing on companies we found that in some cases change in price is appeared before disclosure of forecast. This proves that in these cases we have high probability of private information trading.

Table 6: list of companies that $\mathrm{H}_{2}$ is accepted for them

\begin{tabular}{|c|c|c|c|c|}
\hline \multicolumn{2}{|c|}{} & \multicolumn{3}{c|}{ Reasons for accepting Hypothesis 1 } \\
\cline { 3 - 5 } \multicolumn{2}{|c|}{ Industry Name } & Timely Disclosure & $\begin{array}{c}\text { Significant } \\
\text { Change in } \\
\text { Reported Value }\end{array}$ & $\begin{array}{c}\text { Rumors(Price } \\
\text { manipulation) }\end{array}$ \\
\hline 1 & Metal Ores Mining & $\checkmark$ & $\checkmark$ & - \\
\hline 2 & Food and Non-sugar Products & $\checkmark$ & $\checkmark$ & - \\
\hline 3 & Machinery \& Equipment & $\checkmark$ & - & $\checkmark$ \\
\hline
\end{tabular}

Table 7: list of companies that $\mathrm{H}_{2}$ is rejected for them

\begin{tabular}{|c|c|c|c|c|}
\hline \multicolumn{2}{|c|}{} & \multicolumn{2}{c|}{ Reasons for Rejecting Hypothesis 1 } \\
\cline { 3 - 5 } \multicolumn{2}{|c|}{ Industry Name } & $\begin{array}{c}\text { Timely } \\
\text { Disclosure }\end{array}$ & $\begin{array}{c}\text { No Significant } \\
\text { Change in Reported } \\
\text { Value }\end{array}$ & $\begin{array}{c}\text { Change in price } \\
\text { before } \\
\text { disclosure }\end{array}$ \\
\hline 1 & Pharmaceuticals & - & - & $\checkmark$ \\
\hline 2 & Chemicals \& By-products & - & $\checkmark$ & - \\
\hline 3 & Cement, Lime \& Gypsum & - & $\checkmark$ & - \\
\hline 4 & Other Non-metallic Mineral Products & - & $\checkmark$ & - \\
\hline 5 & Motor Vehicles And Auto Parts & - & $\checkmark$ & - \\
\hline 6 & Basic Metals & - & $\checkmark$ & \\
\hline 7 & Other Financial Intermediaries & - & $\checkmark$ & - \\
\hline 8 & Textiles & - & & \\
\hline
\end{tabular}


Because of same reason as previous hypothesis, we have 2 industries which were candidate for price manipulation investigation and also 2 industries for prices change before disclosure date although they have no significant change in their reported values.

Prices change before disclosure date would be results of information asymmetry. So, we can investigate them for finding evidence about private information trading in these companies.

\section{SUMMARY AND CONCLUSION}

In this research we examined the relation between forecasting report mandatory disclosure and stock price fluctuation. Hypothesizes of this research examine the relationship between two variables over three years ending to 2012.

We found evidence of fluctuation in stock prices before disclosure indicate that information was released to the market before official disclosure. In the other word, stock prices react to the unofficially released information and rumors to the market around the releasing new officially disclosure date. This fraudulent attempt was initiated by price manipulation in cases which we don't see significant price change during forecasted disclosure even if there are significant change in reported earning values.

Results of the first hypothesis showed that there was a significant relationship between releasing forecasted information and stock price fluctuations in the listed companies in TSE. This effect also represented importance of this information to the investor in TSE.

In the next hypothesis we analyzed this effectiveness in companies and industries as the whole. Results of the second hypothesis showed that there was a significant relationship between releasing forecasted information and stock price fluctuations in the listed industries in TSE. These industries were selected among industries that had timely forecast disclosure in adapting to SEO's rule.

We found that fraudulent attempts in the market exchange including price manipulation and insider trading were increasing during research period. Nevertheless, the public policy implications of our results are that, regulators should not fall back on a catch-all requirements to ensure managements realistic forecast but they should motivate companies to early rather than timely disclosures of price-sensitive information to public for preventing from further information asymmetry.

\section{Acknowledgement}

Authors want to thanks Dr.Osmani and Dr.Sadr Ara for their kindly remarks during this research.

\section{REFERENCES}

[1] Aboodya, D., Kasznik, R., 2000, CEO stock option awards and the timing of corporate voluntary disclosures, Journal of Accounting and Economics, Vol. 29-1.

[2] Adina, P., \& Ion, P., 2008, Aspects regarding corporate mandatory and voluntary disclosure. Annals of the University of Oradea: Economic Science, 3(1), 1407-1411.

[3] Ahmadpour Kasgari , A., Bagherian Kasgari, R. \& Bagherian Kasgari, A., 2009, "The Feasibility of eXtensible Business Reporting Language for Listed Companies on Tehran Stock Exchange", (English abstract and Full text in Farsi), Quarterly Journal of Securities Exchange, Volume 2, No 6.

[4] Akhtaruddin, M., 2005, Corporate disclosure practices in Bangladesh. The International Journal of Accounting, 40, 399-422. http://dx.doi.org/10.1016/j.intacc.2005.09.007

[5] Al-Htaybat, K., \& Napier, C., 2006, A framework for financial disclosure theories. Working paper, School of Management University of Southampton.

[6] Bagherian Kasgeri, A., 2007, First Iranian Comprehensive Conference of Electronic Stock Exchange, Islamic Azad University of Qazvin.

[7] Bagherian Kasgeri, A., 2007, Electronic Stock Exchange, Standards and Intelligent Surveillance Networks, Bourse Journal, Securities and Exchange Organization of Iran Monthly Journal.

[8] Bagherian Kasgeri, A., 2007, Software Services in OTC Markets, Bourse Journal, Securities and Exchange Organization of Iran Monthly Journal.

[9] Bagherian, Kasgeri, A., 2007, Bagherian Kasgeri, Roghaye, Intelligent Pyramid Continues Auditing Agent Framework for Softening SOX Burden on Small Business Public Stock Companies, X International Congress on Innovations in Teaching Accounting and Business International Research Conference for Accounting Educators in México City.

[10] Barako, D., Hancock, P., \& Izan, H., 2006, Factors influencing voluntary corporate disclosure by Kenyan companies. Corporate Governance: An International Review, 14(2), 107-125. http://dx.doi.org/10.1111/j.1467-8683.2006.00491.x 
[11] Bikki Jaggi ·Chen-lung Chin ·Hsiou-wei William Lin ·Picheng Lee, 2006, Earnings forecast disclosure regulation and earnings management: evidence from Taiwan IPO firms , pp1-26.

[12] Bruslerie, H., \& Gabteni, H., 2010, Voluntary financial disclosure, introduction of IFRS and the setting of a communication policy: An empirical test on SBF French firms using a publication score. Multinational Financial Society, Barcelona: Espagne.

[13] Chau, G. K., J. Gray, S., 2002, Ownership structure and corporate voluntary disclosure in Hong Kong and Singapore, The International Journal of Accounting, Volume 37, Issue 2, PP. 247-265.

[14] Chen, S., L. DeFond, M., W. Park, C., 2002, Voluntary disclosure of balance sheet information in quarterly earnings announcements, Journal of Accounting and Economics, Volume 33, Issue 2, PP. 229251.

[15] Chena, S., Mark L. DeFonda, Chul W. Parkb, 2002, Voluntary disclosure of balance sheet information in quarterly earnings Announcements, Journal of Accounting and Economics, Volume 33, Issue 2, , Pages 229-251.

[16] Chenga, E. C.M., M. Courtenay, S., 2006, Response to discussion of "board composition, regulatory regime and voluntary disclosure, The International Journal of Accounting, Volume 41, Issue 3, PP. 293294.

[17] Cox, C., 1985, Further Evidence on the Representativeness of Management Earnings Forecasts , The Accounting Review, 60(4): 692-701.

[18] Darrough, M. N., 1993, Disclosure policy and competition: Cournot vs. Bertrand. The Accounting Review,68(3), 534-561

[19] Debrecenya, R., Rahman, 2005, A., Firm-specific determinants of continuous corporate disclosures , The International Journal of Accounting Volume 40, Issue 3, PP. 249-278.

[20] Efron, B., Tibshirani, R., (1993). An introduction to the bootstrap. New York7 Chapman \& Hall.

[21] Einhorn, E., 2005, The nature of the interaction between mandatory and voluntary disclosures. Journal of Accounting Research, 43(4), 593-621. http://dx.doi.org/10.1111/j.1475-679X.2005.00183.x

[22] Einhorn, E., 2007, Voluntary disclosure under uncertainty about the reporting objective, Journal of Accounting and Economics, Volume 43, Issues 2-3, PP. 245-274.

[23] Entwistle, G. M., 1997, Managing disclosure: The case of research and development in knowledge-based firms. (PhD Thesis). The University of Western Ontario, Canada.

[24] Erickson a., M., Wang, Shiing-wu, 1999, Earnings management by acquiring firms in stock for stock mergers, Journal of Accounting and Economics, PP. 149-176.

[25] Fama, E. F., 1970, Efficient Capital Markets: A Review of Theory and Empirical Work, The Journal of Finance, Vol. 25, No. 2, pp. 383-417.

[26] Foster, G., 1973, Stock market reactions to estimates of earnings per share by company officials. Journal of Accounting Research: 25-37.

[27] Gietzmann, M., 2006, Disclosure of Timely and Forward-Looking Statements and Strategic Management of Major Institutional Ownership, pp 409-427.

[28] Gourieroux, C.,\& Joann Jasiak, 2001, financial econometrics (problems, models, and methods), pp. 4041.

[29] Hassell J., R. Jennings, and D. Lasser, 1988, Management Earnings Forecasts: Their Usefulness as a Source of Firm-Specific Information to Security Analysts, The Journal of Financial Research 11(4), 303319.

[30] Healy, P. and K. Palepu, 2001, Information Asymmetry, Corporate Disclosure, and the Capital Markets: A Review of the Empirical Disclosure Literature, Journal of Accounting and Economics, 31, 405-440.

[31] Healy, P. M., Hutton, A. P., \& Palepu, K. G., 1999, Stock performance and intermediation changes surrounding sustained increases in disclosure. Contemporary Accounting Research, Fall, 485-520. http://dx.doi.org/10.1111/j.1911-3846.1999.tb00592.x

[32] Healy, P. M., Palepu K. g., 1993, The effect of firms and financial disclosure strategies on stock prices, the accounting horizons, pp1-10.

[33] Hendriksen, E. S., Van Breda, M. F., 1991, Accounting Theory, Irwin Professional Publishing; 5 Sub edition, P.854, PP. 526-543.

[34] Hussainey, K., \& Walker, M., 2009, The effects of voluntary disclosure and dividend propensity on prices leading earnings. Accounting and Business Research, 39(1), 37-55. http://dx.doi.org/10.1080/00014788.2009.9663348 
[35] Hussainey, K., Schleicher, T., \& Walker, M., 2003, Undertaking large-scale disclosure studies when AIMR-FAF ratings are not available: the case of prices leading earnings. Accounting and Business Research, 33(4), 275-294. http://dx.doi.org/10.1080/00014788.2003.9729654

[36] latridis, G., 2008, Accounting disclosure and firms' financial attributes: Evidence from the UK stock market. International Review of Financial Analysis, 17, 219-241. http://dx.doi.org/10.1016/j.irfa.2006.05.003

[37] latridis, G., 2008, Accounting Disclosure and Firms' Financial Attributes; Evidence from the UK Stock Market, International Review of Financial Analysis, 17 (2), 219-241.

[38] Iran Audit Organization, 1978, Statement of financial accounting concept, No.1, objectives of financial reporting business, PP. 30-34.

[39] Iran Audit Organization, 2005, Auditing Standards, Vol 340, Examination of Prospective Financial Information, Islamic Republic of Iran Audit Organization (IRIAO).

[40] Jo, H., Kim, Y., 2007, Disclosure frequency and earnings management, Journal of Financial Economics, Volume 84, Issue 2, PP. 561-590.

[41] Lang, M. and R. Lundholm, 2000, Voluntary Disclosure during Equity Offerings: Reducing Information Asymmetry or Hyping the Stock? Contemporary Accounting Research, 17, 623-662.

[42] Luoa, S., M. Courtenayb, S., Hossain, M., 2006, The effect of voluntary disclosure, ownership structure and proprietary cost on the return-future earnings relation, Pacific-Basin Finance Journal, Volume 14 Issue 5, PP. 501-521.

[43] Maheshwari, S.N., \& Maheshwari, S.K., 2009, Fundamentals Of Accounting For Cpt (For CA Foundation Course), p121.

[44] Miraskari, S., Sadr Ara, M., \& Jafari, A., 2011, "Evaluation of daily return behavior of Tehran Stock Exchange (TSE)", International Bulletin Of Business Administration (IBBA) Issue 1.

[45] Moonitz, M., 1961, The basic postulates of accounting, accounting research study\#1, American institute of certified public accountants.

[46] Noe, C. F., 1999, Voluntary disclosures and insider transactions, Journal of Accounting and Economics. pp 305- 326.

[47] Omar, B., \& Simon, J., 2011, Corporate aggregate disclosure practice in Jordan. Advances in Accounting,incorporating Advances in International Accounting, 27, 166-186. http://dx.doi.org/10.1016/j.adiac.2011.05.002

[48] P. Jones, C., 2007, Investments: Analysis and Management, 9th Ed, PP. 297-298, Wiley.

[49] Patell, J. M., 1976, Corporate Forecasts of Earnings Per Share and Stock Price Behavior: Empirical Test, Journal of Accounting Research, pp. 246-276.

[50] Razaur Rahmana, A., Teck Meng Tayb, Beng Teck Ongb \& Caib, S., 2007 Quarterly reporting in a voluntary disclosure environment: Its benefits, drawbacks and determinants, The International Journal of Accounting, Volume 42, Issue 4, PP. 416-442.

[51] Sadr Ara. M, Jafari. A, Masoomi. G. \& Firooznia. A., 2011, "The Evaluation of Influential Factors in the level of Banks' Credit Managers Trust in Financial statements", Economics and Finance Review (EFR), Vol.1, No. 6.

[52] Saeedi. A, Miraskari. S. \& Sadr Ara. M., 2012,"The Investigation of Efficient Market Hypothesis: Evidence from an Emerging Market", The Third Asian Business \& Management Conference, The Ramada Osaka, Osaka, Japan.

[53] Sarmad, Z., Bazargan A, Hejazi A., 2000, Research methods in behavioral sciences] [in Farsi].Tehran: Samt Press.PP. 82-91.

[54] Suijs, J., 2008, On the Value Relevance of Asymmetric Financial Reporting Policies, Journal of Accounting Research, vol. 46, issue 5, PP. 1297-1321.

[55] Taplin, R., Tower, G., \& Hancock, P., 2002, Disclosure (discernibility) and compliance of accounting policies:Asia-Pacific evidence. Accounting Forum, 26(2), 172-190. http://dx.doi.org/10.1111/14676303.00085

[56] Tehran Stock Exchange, 2005, Rules and Laws Collection Series for Tehran Stock Exchange, Edition 5, for Tehran Stock Exchange's Information Dissimilation, PP. 110-111.

[57] Watts, R., \& Zimmerman, J., 1986, Positive Accounting Theory. Englewood Cliffs, NJ: Prentice-Hall.

[58] Wolk, H. I., Dodd, J. L. \& Tearney, M. G., 2000, Accounting Theory, Sixth Edition, p138.

[59] Yu, J., 2011. The interaction of voluntary and mandatory disclosures: Evidence from the SEC's elimination of the IFRS-U.S. GAAP Reconciliation. Working Paper, Nanyang Technological University (Singapore). 